Article

\section{MENDES FAGHERAZZI, M. ${ }^{1}$}

SOUZA, C.A. ${ }^{1 *}$

STEFEN, D.L.V. ${ }^{1}$

ZANESCO, P.R. ${ }^{1}$

JUNKES, G.V. ${ }^{1}$

COELHO, C.M.M. ${ }^{1}$

SANGOI, L. ${ }^{1}$

\section{* Corresponding author:}

<clovis.souza@udesc.br>

\section{Received: May 9, 2016}

Approved: October 13, 2016

\section{Planta Daninha 2018; v36:e018154739}

Copyright: This is an open-access article distributed under the terms of the Creative Commons Attribution License, which permits unrestricted use, distribution, and reproduction in any medium, provided that the original author and source are credited.

\title{
Phenological Sensitivity of Two Maize Cultivars to TRINEXAPAC-ETHYL
}

\author{
Sensibilidade Fenológica de Dois Cultivares de Milho a Trinexapac-Ethyl
}

ABSTRACT - In Brazilian agriculture there are few reports on trinexapac-ethyl (TE) effects on maize plant lodging management. This study aimed to evaluate the effects of sequential application of TE sprayed on different plant growth stages of maize using the simple hybrid P30F53HR and the variety SCS 154 Fortuna. Experiments were carried out in a greenhouse in the 2013 and 2014 harvests. Plants were grown singly in 5L pots filled with $75 \%$ soil and $25 \%$ substrate. The experimental design was a randomized complete block with four replications. The following treatments were performed: (T1) control (no application of growth retardant); (T2) application at V2 (100 g a.i. ha-1); (T3) sequential application of $100 \mathrm{~g}$ a.i. ha ${ }^{-1}$ at V2 plus V3; (T4) sequential application of $100 \mathrm{~g}$ a.i. ha ${ }^{-1}$ at $\mathrm{V} 2+\mathrm{V} 3+\mathrm{V} 4$; (T5) single application of $300 \mathrm{~g}$ a.i. ha ${ }^{-1}$ at V4; (T6) sequential application of $100 \mathrm{~g}$ a.i. ha ${ }^{-1}$ at V2+V3+V4+V5; (T7) sequential application of $100 \mathrm{~g}$ a.i. ha $\mathrm{a}^{-1}$ at $\mathrm{V} 2+\mathrm{V} 3+\mathrm{V} 4+\mathrm{V} 5+\mathrm{V} 6$ and (T8) sequential application of $100 \mathrm{~g}$ a.i. ha ${ }^{-1}$ at $\mathrm{V} 2+\mathrm{V} 3+\mathrm{V} 4+\mathrm{V} 5+\mathrm{V} 6+\mathrm{V} 7$. The some morphological characteristics of the two maize genotypes changed in response to TE treatment. From stage V4 onwards, maize plant height showed signs of sensitivity to the growth retardant. Plants in T8 (TE applied over V2 to V7) were more sensitive to TE with over $45 \%$ reduction in plant height compared with application T7 (applied from V2 to V6). This response was similar in both maize genotypes, thus indicating that plants are highly sensitive to TE after the V6 stage.

Keywords: Zea mays L., growth regulator, morphological characteristics.

RESUMO - Na cultura do milho há poucos relatos sobre o uso de trinexapac-ethyl (TE) visando o manejo do acamamento de plantas. Este estudo teve por objetivo avaliar diferentes doses sequenciais de TE aplicadas em diferentes estádios fenológicos da planta de milho, utilizando o híbrido simples P30F53HR e a variedade SCS 154 Fortuna. Os experimentos foram realizados em casa de vegetação em dois anos de cultivo: 2013 e 2014. Foram empregados vasos com capacidade para 5 L, preenchidos com $75 \%$ de solo e $25 \%$ de substrato comercial, com uma planta de milho por vaso. $O$ delineamento experimental foi de blocos ao acaso com quatro repetições. Os tratamentos consistiram de: (T1) testemunha (sem aplicação de regulador); (T2) aplicação em V2 (100 g i.a. ha $\left.{ }^{-1}\right)$; (T3) aplicação de $100 \mathrm{~g}$ i.a. $\mathrm{ha}^{-1}$ em V2+V3; (T4) aplicação de $100 \mathrm{~g}$ i.a. $\mathrm{ha}^{-1} \mathrm{em} \mathrm{V2+V3+V4;} \mathrm{(T5)} \mathrm{única} \mathrm{aplicação}$ de 300 g i.a. ha $a^{-1}$ em V4; (T6) aplicação de 100 g i.a. ha $a^{-1}$ em V2+V3+V4+V5; (T7) aplicação de $100 \mathrm{~g}$ i.a. ha $a^{-1}$ em V2+V3+V4+V5+V6; e (T8) aplicação de 100 g i.a. ha $a^{-1}$ em V2+V3+V4+V5+V6+V7. A partir do estádio V4 as plantas de milho apresentaram sinais de sensibilidade ao regulador de crescimento; a aplicação de V2 a V7 (T8), comparada à de V2 a V6 (T7), evidenciou que as plantas foram mais sensiveis ao TE, com redução superior a $45 \%$ na estatura de planta - resposta esta similar entre os dois genótipos de milho. Os resultados indicam que após o estádio V6 as plantas são altamente sensiveis ao trinexapac-ethyl.

Palavras-chave: Zea mays L., regulador de crescimento, características morfológicas.

1 Universidade do Estado de Santa Catarina - UDESC, Lages-SC, Brasil. 


\section{INTRODUCTION}

Maize is the most frequently cultivated cereal in the world, with production exceeding 900 million tons grown on 175 million hectares. In the 2012/2013 the average grain yield in the world was 5.19 ton $\mathrm{ha}^{-1}(\mathrm{FAO}, 2014)$. Over the last five growing season, the average world consumption of maize increased by $12 \%$, representing an increase of 93 million tons in absolute terms (FAO, 2014). Brazil produced 72 million tons of maize in the 2010/2011 growing season and the 82 million tons in the 2012/2013 growing season, showing an increasing around 3 million tons of maize per yiear (Conab, 2015). Currently, the average agricultural grain yield of maize in Brazil is 5.07 ton ha $^{-1}$ (Conab, 2015).

Increasing productivity is a constant challenge for the maize production chain, and higher levels can be achieved when some management practices are changed. One of the most important practices used for achieving higher agricultural grain yield is to make changes in the spatial arrangement of plants (Almeida et al., 2000). In this regard, population density has the biggest effect on maize grain yield, because small changes in population density produce relatively large changes in crop yield. For example, grain yields higher than 18 ton ha ${ }^{-1}$ were obtained with densities greater than $9 \mathrm{pl} \mathrm{m}^{-2}$, but only in experimental conditions (Assis et al., 2006; Silva et al., 2006; Sangoi et al., 2015).

Maize is one of the most efficient species in converting solar radiation into phytomass (Sangoi et al., 2013). Providing a plant crop community with maximum incident radiation can be a useful strategy to increase grain yield. Conceptually, optimum use of solar radiation is achieved with the adoption of high plant densities $\left(7-9 \mathrm{pl} \mathrm{m}^{-2}\right)$ and reduced row spacing $(45-50 \mathrm{~cm})$ in order to capture maximum incident radiation and maintain this maximum constant over a long period of time (Sangoi et al., 2013).

The use of high plant densities (higher than $9 \mathrm{pl} \mathrm{m}^{-2}$ ) in maize crops is limited because crops tend to become susceptible to lodging, and etiolation and self-shading among the leaves increases. The use of maize cultivars with shorter plant height and associated smaller and more erect leaves can minimize such problems (Gong et al., 2015). However, currently this plant ideotype is not predominant among those available to farmers. Therefore, the adoption of other management techniques, such as the use of growth regulators, is necessary.

Plant growth regulators affect plant physiology in order to alter features of leaf architecture and reduce stem height in order to facilitate cultivation, reduce propensity to lodging, maximize absorption of solar radiation and, thus, increase grain yield. The use of high plant densities in maize cultivation is based on management strategies that allow a plant stand to achieve an agricultural grain yield of over 12 ton $\mathrm{ha}^{-1}$. These strategies include the increase use of inputs such as fertilizers, particularly nitrogen, and pest and disease control (Sangoi et al., 2015), and, more recently, the possible use of growth regulators (Zhang et al., 2014).

Studies conducted with wheat crops have demonstrated the ability to decrease plant height by using growth regulators, particularly trinexapac-ethyl (TE). This regulator acts on plants by reducing cell elongation in the vegetative stage and temporarily blocking the biosynthesis of gibberellic acid (Heckman et al., 2002), thereby sharply increasing its immediate biosynthetic precursor gibberellin 20-oxidase (GA20) (Davies, 1987). The probable cause of plant growth inhibition by application of TE is the decrease in the level of active gibberellic acid GA1 engaged in the elongation of internodes (Weiler and Adams, 1991).

The TE treatments have been stressed as effective technique in reducing plant height and improving leaf architecture of wheat (Zagonel and Fernandes, 2007). The likely cause for excessive growth in height of maize plants may be associated with a high concentration of gibberellic acid at the time of stem elongation. But the possibility of using growth retardants in maize crops is still incipient (Zagonel and Ferreira, 2013; Zhang et al., 2014) and there is a lack of basic information about the behavior of vegetative structures of maize plants after application of TE. Stem length, particularly internode length, is the main target of manure due use of TE for becoming shorter plants and, possibly make them more tolerant to lodging.

To gather further information on the response of maize plants to the use of trinexapac-ethyl (TE), this study aimed to evaluate the effects of sequential application of TE applied at different 
growth stages on morphological characteristics and biological yield in two maize genotypes contrasting in genetic variability have different yield potential: a simple hybrid and other an open-pollinated variety.

\section{MATERIAL AND METHODS}

Two experiments were undertaken in two growing seasons, from August 18, 2013 to December 19, 2013 in first season and, form October 1, 2014 to February 2, 2015. in a greenhouse at the Center for Veterinary and Agricultural Sciences, Santa Catarina State University, located in Lages, in the southern highlands of the state of Santa Catarina - Brazil $\left(27^{\circ} 47^{\prime} \mathrm{S}, 50^{\circ} 18^{\prime} \mathrm{W}\right.$; $930 \mathrm{~m})$.

Two maize genotypes were used: the early-maturing simple hybrid P30F53HR developed by the company Pioneer, which is characterized by having plants whose height and ear insertion were 260 and $110 \mathrm{~cm}$, respectively; among hybrids cropped and commercialized in Santa Catarina state the P30F53HR has been one of the most cultivated in the last ten crop seasons with grain yield potential higher than 12 ton $\mathrm{ha}^{-1}$. The other genotype are an early-maturing open-pollinated variety (OPV) SCS 154 Fortuna developed by EPAGRI, whose average plant height was $230 \mathrm{~cm}$ and ear insertion was $120 \mathrm{~cm}$, and which is adapted to the west and north mesoregions of the Santa Catarina plateau and seasons with grain yield potential around 6 ton ha ${ }^{-1}$ (Grupo Cultivar de Publicações, 2012); This genotype is extensive cultivation among farmers family based in Santa Cataina. In this sense it was performed the choice of two contrasting genotypes for our experiments. Seeds were sown in $5 \mathrm{~L}$ plastic pots measuring $23 \mathrm{~cm}$ in diameter and $23 \mathrm{~cm}$ in height and filled with 25\% substrate (AgroCerro) and 75\% soil classified as a Haplumbrept.

The mixture substrate+soil was chemically analyzed. The initial analysis of the mixture showed $51.0 \%$ clay content, organic matter $3.0 \%$, soil CEC at $\mathrm{pH} 7.0,18.2 \mathrm{cmol}_{\mathrm{c}} \mathrm{dm}^{-3}$ and water $\mathrm{pH}$ 5.6. The initial levels of nutrients were $\mathrm{Ca}=6.20 \mathrm{cmol}_{\mathrm{c}} \mathrm{dm}^{-3}, \mathrm{Mg}=3.13 \mathrm{cmol}_{\mathrm{c}} \mathrm{dm}^{-3}$, $\mathrm{P}=37.9 \mathrm{mg} \mathrm{dm}^{-3}, \mathrm{~K}=75 \mathrm{mg} \mathrm{dm}^{-3}, \mathrm{H}+\mathrm{Al}=8.70 \mathrm{cmol}_{\mathrm{c}} \mathrm{dm}^{-3}$ and $\mathrm{Al}=0.0 \mathrm{cmol}_{\mathrm{c}} \mathrm{dm}^{-3}$. The mixture substrate+soil were corrected following the rules of the Soil Chemistry and Fertility Commission (CQFSRS/SC, 2004) to obtain a grain yield equivalent of 12 ton ha ${ }^{-1}$.

The experimental design was a randomized block with eight treatments and four replications. Four seeds were sown in each pot, and the plants were thinned when they were at the V3 stage, according to the scale of Ritchie et al. (1993). Only one plant was kept per pot, and the position of the pots was changed on the bench every 15 days. The greenhouse environments were composed by natural lighting and internal air temperature controlled to $25 \pm 10{ }^{\circ} \mathrm{C}$ and relative humidity ranged 60 to $80 \%$. The external daily solar radiation and temperature are showed at Figure 1. Each cultivar consisted of one experiment and was analyzed separately because of the tendency to get more accurate management information when the use of agricultural inputs for maize cultivation is associated with specific recommendations per cultivar, for example seeding rate.

The growth regulator trinexapac-ethyl - TE (Moddus ${ }^{\circledR}$ ) was applied to the plants between the growth stages V2 and V7 (i.e., two to seven fully expanded leaves) with the following sequential applications according to phenological stage: (T1) control (no regulator application); (T2) application at V2 (100 g a.i. $\left.\mathrm{ha}^{-1}\right)$; (T3) sequential application of $100 \mathrm{~g}$ a.i. ha ${ }^{-1}$ at V2+V3 accumulating $200 \mathrm{~g}$ a.i. ha ${ }^{-1}$; (T4) sequential application of $100 \mathrm{~g}$ a.i. $\mathrm{ha}^{-1}$ at $\mathrm{V} 2+\mathrm{V} 3+\mathrm{V} 4$ accumulating $300 \mathrm{~g}$ a.i. ha-1; (T5) single application of $300 \mathrm{~g}$ a.i. ha $\mathrm{g}^{-1}$ at V4; (T6) sequential application of $100 \mathrm{~g}$ a.i. ha ${ }^{-1}$ at V2+V3+V4+V5 accumulating $400 \mathrm{~g}$ a.i. ha-1; (T7) sequential application of $100 \mathrm{~g}$ a.i. ha ${ }^{-1}$ at $\mathrm{V} 2+\mathrm{V} 3+\mathrm{V} 4+\mathrm{V} 5+\mathrm{V} 6$ accumulating $500 \mathrm{~g}$ a.i. ha ${ }^{-1}$, and (T8) sequential application at $100 \mathrm{~g}$ a.i. ha ${ }^{-1}$ at $\mathrm{V} 2+\mathrm{V} 3+\mathrm{V} 4+\mathrm{V} 5+\mathrm{V} 6+\mathrm{V} 7$ accumulating $600 \mathrm{~g}$ a.i. ha ${ }^{-1}$.

TE was applied with a $\mathrm{CO}_{2}$-pressurized backpack sprayer with constant pressure of $30 \mathrm{lb} \mathrm{pol}^{-2}$. Tips with XR 110-015 flat fan nozzles calibrated for spray volume at $200 \mathrm{~L} \mathrm{ha}^{-1}$ were used. During application, the spray was directed to the whorl of each plant.

When the plants reached the silking stage, the following variables were assessed: (i) plant height, from the ground to the base of the blade of the last leaf; (ii) ear insertion height, from the ground to the base of the leaf blade of the index leaf (height in both $i$ and ii was performed with a measuring tape); (iii) stem diameter was evaluated on the second internode above the ground 
(A)

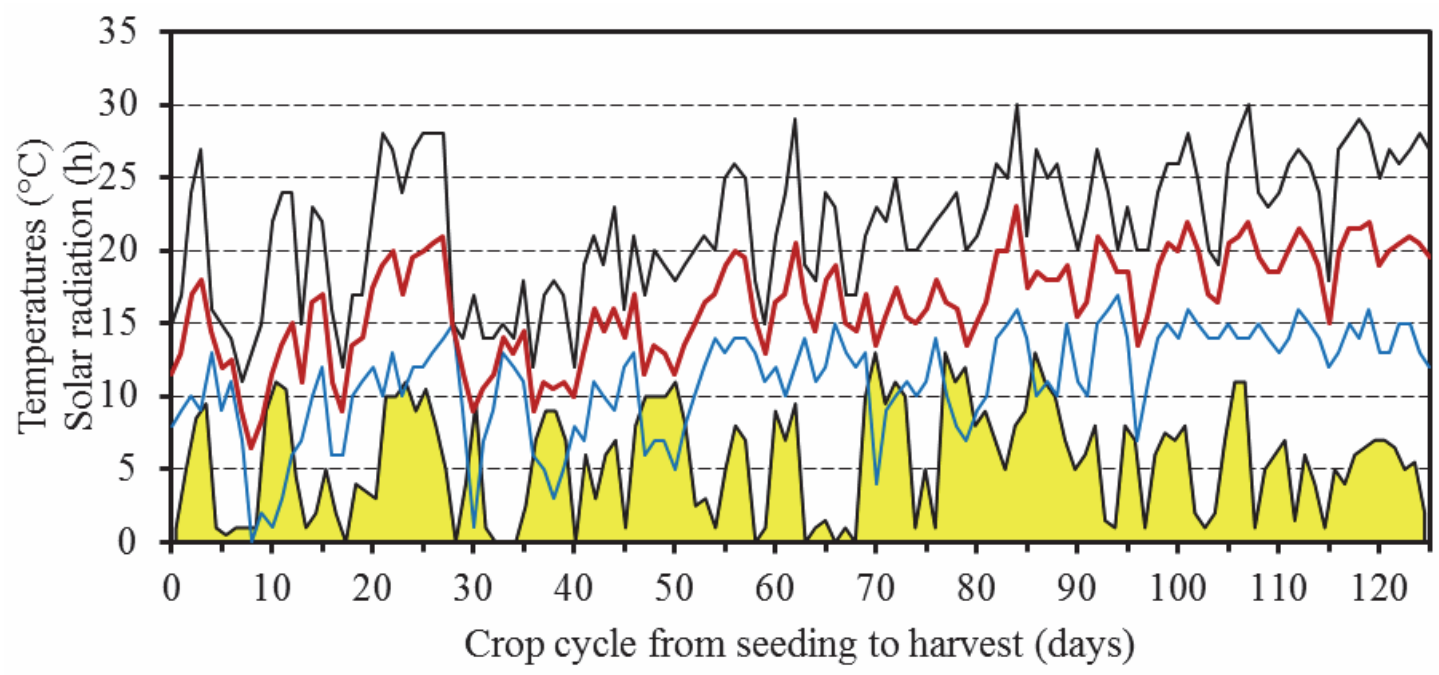

Crop cycle from seeding to harvest (days)

(B)

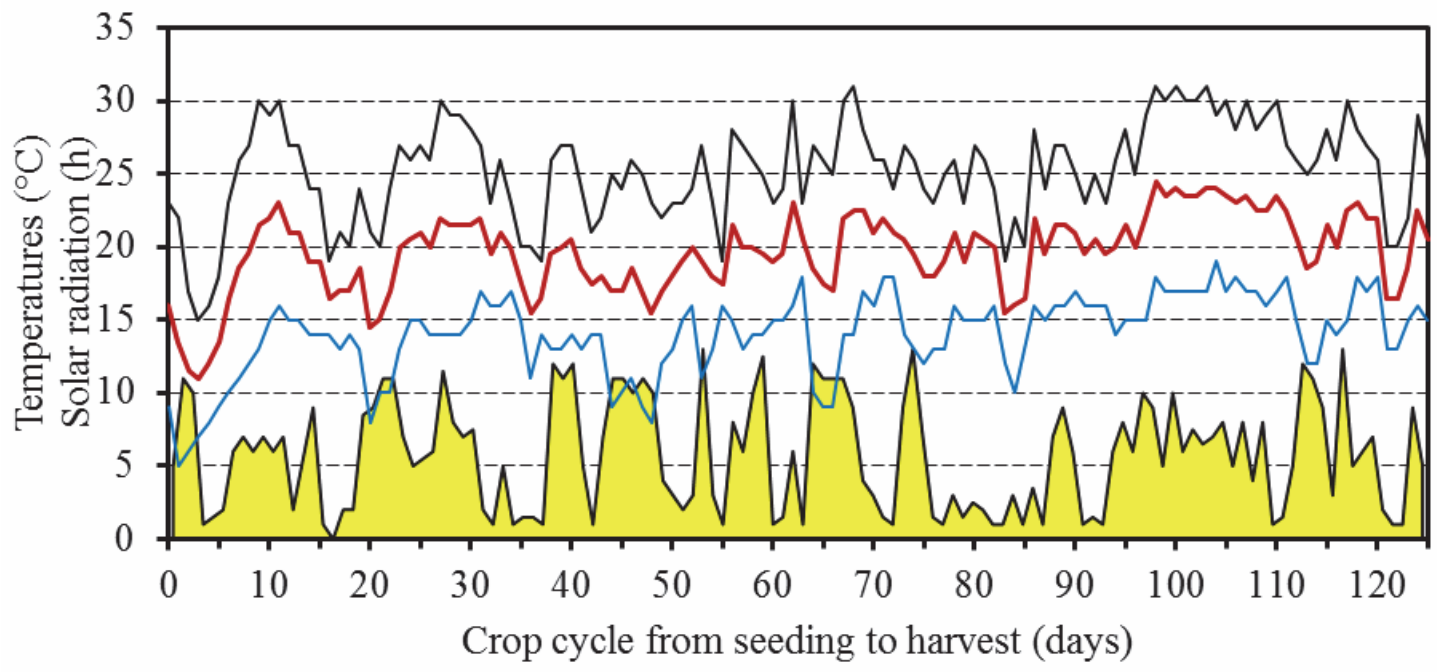

$\square$ solar rad. (h) $\quad-\mathrm{T}^{\circ} \mathrm{C} \max . \quad-\mathrm{T}^{\circ} \mathrm{C}$ min. $\quad-\mathrm{T}^{\circ} \mathrm{C}$ average

Figure 1 - Temperatures (maximum, minimum and average) and solar radiation incidence diary from seeding to harvest of maize treated with trinexapac-ethyl, during 2013 (A) and 2014/2015 (B) growing seasons. Lages, 2015.

with a digital caliper; (iv) the number of fully grown leaves on plants was determined by direct counting; (v) biological yield per plant was measured after drying in a forced air oven at $60{ }^{\circ} \mathrm{C}$ until constant weight and (vi) the time to tasseling, the number of days until tasseling date. The assay of first season was seeded at August 18, 2013 and harvested at December 19, 2013 e the second season was seeded at October 1, 2014 e harvested at February 2, 2015.

Data were subjected to analysis of variance using the $\mathrm{F}$ test at $5 \%$ level of probability. When significant, the means were compared by the Scott-Knott test $(p<0.05)$. The analyses were performed with the aid of SISVAR® software (Ferreira, 2011).

\section{RESULTS AND DISCUSSION}

For the hybrid P30F53HR, the variables plant height, ear insertion height, time to male flowering and biological yield were the parameters that showed interactions between the year of assessment and the different TE treatments (Table 1). In the open-pollinated cultivar SCS 154 Fortuna, variables that showed interaction between year and the treatments were time to tasseling and biological yield (Table 1). 
Table 1 - Analysis of variance (MS - mean square) for the traits plant height (PH), ear insertion height (EIH), stem diameter (SD), number of leaves per plant (NL), time to tasseling (TT) and biological yield (BY) in maize hybrid P30F53HR and cultivar SCS 154 Fortuna, under sequential application of regulator in the 2013 and 2014/2015 growing seasons. Lages-SC, 2015

\begin{tabular}{|c|c|c|c|c|c|c|c|}
\hline \multirow{2}{*}{$\mathrm{SV}^{(1)}$} & \multirow{2}{*}{$\mathrm{DG}^{(2)}$} & $\mathrm{PH}$ & EIH & SD & NL & TT & $\mathrm{BY}$ \\
\hline & & $(\mathrm{cm})$ & $(\mathrm{cm})$ & $(\mathrm{mm})$ & $\left(n^{0}.\right)$ & (days) & (g) \\
\hline \multicolumn{8}{|c|}{ MS to P30F53HR } \\
\hline Season $(\mathrm{S})^{(3)}$ & 1 & $10353.1^{* *}$ & $4795.6^{* *}$ & $28.6^{*}$ & $72.3 * *$ & $248.1 * *$ & $172017.6^{* *}$ \\
\hline Treatment $(T)^{(4)}$ & 7 & $4373.3 * *$ & $2393.9 * *$ & $14.3 *$ & $1.5 \mathrm{~ns}$ & $15.1 * *$ & $3553.7 * *$ \\
\hline $\mathrm{S} \times \mathrm{T}$ & 7 & $1035.5^{* *}$ & $808.8^{* *}$ & $6.9 \mathrm{~ns}$ & $0.8 \mathrm{~ns}$ & $6.5 * *$ & $3103.5 * *$ \\
\hline Mean & & 133.4 & 87.1 & 21.7 & 17.4 & 76.6 & 142.4 \\
\hline $\mathrm{VC} \%$ & & 8.6 & 11.8 & 10.3 & 4.8 & 1.9 & 20.5 \\
\hline \multicolumn{8}{|c|}{ MS to SCS 154 Fortuna } \\
\hline Season (S) & 1 & $20700.1^{* *}$ & $9776.3^{* *}$ & $35.6 * *$ & $90.3 * *$ & $31.6 \mathrm{~ns}$ & $264453.1 * *$ \\
\hline Treatment(T) & 7 & $7274.2 * *$ & $2819.6^{* *}$ & $38.6 * *$ & $2.3 \mathrm{~ns}$ & $49.9 * *$ & $4001.2 * *$ \\
\hline $\mathrm{S} \times \mathrm{T}$ & 7 & $566.9 \mathrm{~ns}$ & $552.7 \mathrm{~ns}$ & $5.5 \mathrm{~ns}$ & $0.8 \mathrm{~ns}$ & $34.3 * *$ & $4149.1 * *$ \\
\hline Mean & & 145.3 & 93.4 & 21.6 & 17.8 & 78.5 & 162.3 \\
\hline $\mathrm{VC} \%$ & & 11.7 & 17.4 & 10.1 & 6.6 & 3.8 & 18.3 \\
\hline
\end{tabular}

** and $*=$ statistically different by the F-test at $\mathrm{p}<0.01$ and $\mathrm{p}<0.05$, respectively; ns: not significant ( $>0.05)$; ${ }^{(1)} \mathrm{SV}=$ sources of variation; (2) $\mathrm{DG}=$ degrees of freedom; ${ }^{(3)} \mathrm{S}=$ growing season; ${ }^{(4)} \mathrm{T}=$ treatments.

The greatest height reductions were observed in the T8 treatment for the hybrid P30F53HR; the second year of evaluation showed lower values in plant height compared with the first year (Table 2). The highest reductions in plant height and ear insertion in both years of evaluation occurred when the maize plants continued to be treated with the growth regulator, mainly in treatments T7 and T8 for the hybrid P30F53HR. These reductions were $49 \%$ and 47\% in 2013 and 2014, respectively, compared with treatment T1 (control). For the open-pollinated variety SCS 154 Fortuna, the results were similar to those observed in the hybrid, with reduction were $45.7 \%$, compared with treatment $\mathrm{T} 1$ (control) (Table 3). There was a reduction by approximately 52 and 44\% in the ear insertion height in T8 when compared to treatment T1 (control) in hybrid P30F53HR and in the OPV SCS 154 Fortuna, respectively (Table 3).

A comparison of plant heights between treatments T4 and T5 for the hybrid P30F53HR showed that plants which received the same amount of TE (300 g a.i. ha ${ }^{-1} \mathrm{TE}$ ) applied at the phenological stage V4, but applied in a sequential manner in T4 and as a single rate in T5, differed, with a reduction occurring only in T5 in the second year of assessment (a difference of $17.7 \mathrm{~cm}$ in T5 compared to T4; Table 2). For plant ear height, T5 also showed a greater reduction than T4 (a difference of $15.2 \mathrm{~cm}$; Table 2). These results indicate that the treatment T5 in the second year (2014) was the most responsive in reducing plant height and ear insertion height, and that better results can be obtained with a single application of $300 \mathrm{~g}$ a.i. ha ${ }^{-1}$ at V4 than its division among three successive applications of $100 \mathrm{~g}$ a.i. ha ${ }^{-1}$ at V2, V3 and V4 (T4).

For the SCS 154 Fortuna, the results were similar to those observed for the hybrid, and the means of treatments T4 and T5, in both growing seasons, showed a lower height for T5 plants (difference of $22.5 \mathrm{~cm}$ ) compared to the T4 plants (Table 3). For T3, only for the SCS 154 Fortuna was there was a modest reduction in plant height $(20 \mathrm{~cm})$ compared to the control (Table 3). This result can be explained by a likely hormonal imbalance caused by the application of TE (200 g a.i. ha $\left.{ }^{-1}\right)$ at the V3 growth stage. For this vegetative plant stage endogenous gibberellin levels are low compared with vegetative stages V5 and later. The V5 stage is characterized by the initiation of cell elongation. Gibberellins are known to play a key role in the establishment of elongation and the maintenance of plant stem growth (Perez-Perez, 2007). Because of this possible hormonal adjustment, TE application prior to V4, can lead to the adverse effect of increased plant height in T3. However, the same behavior was not observed in this cultivar in the second harvest, nor was it observed in the hybrid P30F53HR in either growing seasons.

In the simple hybrid, the application of an extra $100 \mathrm{~g}$ a.i. ha ${ }^{-1}$ in V7, compared to the V6 stage, reduced plant height by $41.5 \mathrm{~cm}$ and $24.2 \mathrm{~cm}$ in the first and second years of the experiment, 
Table 2 - Further analysis of the interaction between growing season and treatments (treat, consisting of sequential application of trinexapac-ethyl at different growth stages) in two maize genotypes, in the growing seasons 2013 and 2014/2015. Lages-SC, 2015

\begin{tabular}{|c|c|c|c|c|c|c|c|c|c|}
\hline \multicolumn{10}{|c|}{ P30F53HR } \\
\hline $\mathrm{SV}^{(1)}$ & Season $^{(2)}$ & $\mathrm{T}^{(3)}$ & $\mathrm{T} 2$ & T3 & $\mathrm{T} 4$ & T5 & T6 & $\mathrm{T} 7$ & T8 \\
\hline \multirow{2}{*}{$\begin{array}{l}\mathrm{PH}^{(4)} \\
(\mathrm{cm})\end{array}$} & 2013 & $189.5 \mathrm{aA}$ & $144.7 \mathrm{aB}$ & $149.7 \mathrm{aB}$ & $150.0 \mathrm{aB}$ & $160.2 \mathrm{aB}$ & $140.5 \mathrm{aB}$ & $138.0 \mathrm{aB}$ & $96.5 \mathrm{aC}$ \\
\hline & 2014 & $141.5 \mathrm{bA}$ & $145.0 \mathrm{aA}$ & $137.0 \mathrm{aA}$ & $119.2 \mathrm{bB}$ & $101.5 \mathrm{bC}$ & $146.2 \mathrm{aA}$ & $99.7 \mathrm{bC}$ & $75.5 \mathrm{bD}$ \\
\hline \multirow{2}{*}{$\begin{array}{l}\mathrm{EIH} \\
(\mathrm{cm})\end{array}$} & 2013 & $130.0 \mathrm{aA}$ & $88.7 \mathrm{aB}$ & $109.5 \mathrm{aA}$ & $97.0 \mathrm{aB}$ & $111.7 \mathrm{aA}$ & $83.0 \mathrm{aB}$ & $89.7 \mathrm{aB}$ & $56.0 \mathrm{aC}$ \\
\hline & 2014 & $89.2 \mathrm{bA}$ & $94.0 \mathrm{aA}$ & $98.2 \mathrm{aA}$ & $78.2 \mathrm{bB}$ & $63.0 \mathrm{bB}$ & $90.0 \mathrm{aA}$ & $65.5 \mathrm{bB}$ & $49.0 \mathrm{aC}$ \\
\hline \multirow{2}{*}{$\begin{array}{l}\text { TT } \\
\text { (days) }\end{array}$} & 2013 & $79.5 \mathrm{aB}$ & $77.2 \mathrm{aC}$ & $77.7 \mathrm{aC}$ & $77.0 \mathrm{aC}$ & $77.5 \mathrm{aC}$ & $79.5 \mathrm{aB}$ & $78.0 \mathrm{aC}$ & $81.7 \mathrm{aA}$ \\
\hline & 2014 & $73.0 \mathrm{bB}$ & $73.5 \mathrm{bB}$ & $73.0 \mathrm{bB}$ & $73.5 \mathrm{bB}$ & $75.2 \mathrm{bA}$ & $74.5 \mathrm{bB}$ & $77.2 \mathrm{aA}$ & $76.7 \mathrm{bA}$ \\
\hline \multirow{2}{*}{$\begin{array}{l}\text { BY } \\
\text { (g) }\end{array}$} & 2013 & $178.7 \mathrm{aB}$ & $176.0 \mathrm{aB}$ & $205.0 \mathrm{aB}$ & $165.0 \mathrm{aB}$ & $290.0 \mathrm{aA}$ & $179.2 \mathrm{aB}$ & $187.5 \mathrm{aB}$ & $172.5 \mathrm{aB}$ \\
\hline & 2014 & $96.2 \mathrm{bA}$ & $92.5 \mathrm{bA}$ & $95.0 \mathrm{bA}$ & $87.5 \mathrm{bA}$ & $92.5 \mathrm{bA}$ & $93.7 \mathrm{bA}$ & $86.2 \mathrm{bA}$ & $80.7 \mathrm{bA}$ \\
\hline \multicolumn{10}{|c|}{ SCS 154 Fortuna } \\
\hline \multirow{2}{*}{$\begin{array}{l}\mathrm{PH} \\
(\mathrm{cm})\end{array}$} & 2013 & $172.0 \mathrm{aA}$ & $176.0 \mathrm{aA}$ & $206.0 \mathrm{aA}$ & $173.0 \mathrm{aA}$ & $151.0 \mathrm{aB}$ & $175.0 \mathrm{aA}$ & $154.0 \mathrm{aB}$ & $98.0 \mathrm{aC}$ \\
\hline & 2014 & $153.0 \mathrm{aA}$ & $155.0 \mathrm{aA}$ & $160.0 \mathrm{bA}$ & $137.0 \mathrm{bA}$ & $114.0 \mathrm{bB}$ & $134.0 \mathrm{bA}$ & $85.8 \mathrm{bC}$ & $78.3 \mathrm{aC}$ \\
\hline \multirow{2}{*}{$\begin{array}{l}\text { EIH } \\
(\mathrm{cm})\end{array}$} & 2013 & $113.3 \mathrm{aA}$ & $111.8 \mathrm{aA}$ & $123.3 \mathrm{aA}$ & $96.6 \mathrm{aA}$ & $95.3 \mathrm{aA}$ & $115.8 \mathrm{aA}$ & $99.3 \mathrm{aA}$ & $87.3 \mathrm{aB}$ \\
\hline & 2014 & $108.3 \mathrm{aA}$ & $106.5 \mathrm{aA}$ & $104.5 \mathrm{bA}$ & $83.3 \mathrm{aB}$ & $67.5 \mathrm{bC}$ & $84.3 \mathrm{bB}$ & $56.5 \mathrm{bC}$ & $37.3 \mathrm{bD}$ \\
\hline \multirow{2}{*}{$\begin{array}{l}\text { TT } \\
\text { (days) }\end{array}$} & 2013 & $79.7 \mathrm{aB}$ & $79.2 \mathrm{aB}$ & $79.0 \mathrm{aB}$ & $76.5 \mathrm{aB}$ & $81.0 \mathrm{aA}$ & $76.5 \mathrm{aB}$ & $77.2 \mathrm{bB}$ & $84.0 \mathrm{aA}$ \\
\hline & 2014 & $75.2 \mathrm{bB}$ & $74.2 \mathrm{bB}$ & $80.2 \mathrm{aA}$ & $74.0 \mathrm{aB}$ & $74.5 \mathrm{bB}$ & $78.0 \mathrm{aB}$ & $83.2 \mathrm{aA}$ & $82.5 \mathrm{aA}$ \\
\hline \multirow{2}{*}{$\begin{array}{l}\text { BY } \\
\text { (g) }\end{array}$} & 2013 & $241.2 \mathrm{aB}$ & $230.0 \mathrm{aC}$ & $215.0 \mathrm{aC}$ & $183.2 \mathrm{aC}$ & $310.0 \mathrm{aA}$ & $255.0 \mathrm{aB}$ & $203.0 \mathrm{aC}$ & $175.0 \mathrm{aC}$ \\
\hline & 2014 & $106.5 \mathrm{bA}$ & $81.2 \mathrm{bA}$ & $98.7 \mathrm{bA}$ & $90.0 \mathrm{bA}$ & $91.2 \mathrm{bA}$ & $105.0 \mathrm{bA}$ & $120.0 \mathrm{bA}$ & $91.2 \mathrm{bA}$ \\
\hline
\end{tabular}

(1) SV, Sources of Variation; (2) Seasons; (3) Treatments: T1 control (0); (T2) V2 (100 g a.i. ha $\left.{ }^{-1}\right)$; (T3)100 g a.i. ha ${ }^{-1}$ at V2 + V3; (T4) $100 \mathrm{~g}$ a.i. ha ${ }^{-1}$ at V2 + V3 + V4; (T5) $300 \mathrm{~g}_{\text {a.i. ha }}{ }^{-1}$ at V4; (T6) $100 \mathrm{~g}$ a.i. ha ${ }^{-1}$ at V2 + V3 + V4 +V5; (T7) $100 \mathrm{~g}$ a.i. ha ${ }^{-1}$ at V2 + V3 + V4 + V5 +V6; (T8) $100 \mathrm{~g}$ a.i. ha ${ }^{-1}$ at $\mathrm{V} 2+\mathrm{V} 3+\mathrm{V} 4+\mathrm{V} 5+\mathrm{V} 6+\mathrm{V} 7$. ${ }^{(4)} \mathrm{PH}=$ plant height; $\mathrm{EIH}=$ ear insertion height, $\mathrm{TT}=$ time to tasseling and $\mathrm{BY}=$ biological yield of the plants. Different lowercase letters in the column and uppercase letters in the row differ according to the Scott-Knott test $(\mathrm{p}<0.05)$.

Table 3 - Effect of treatment (treat, consisting of sequential application of trinexapac-ethyl) observed in two maize genotypes on the traits: $\mathrm{SD}=$ stem diameter, $\mathrm{PH}=$ plant height and $\mathrm{EIH}=$ ear insertion height. In the average of two growing seasons. Lages-SC, 2015

\begin{tabular}{|c|c|c|c|c|c|c|}
\hline \multirow{2}{*}{ Treatment $^{(1)}$} & \multicolumn{3}{|c|}{ P30F53HR } & \multicolumn{3}{|c|}{ SCS 154 Fortuna } \\
\cline { 2 - 7 } & $\begin{array}{c}\mathrm{PH} \\
(\mathrm{cm})\end{array}$ & $\begin{array}{c}\text { EIH } \\
(\mathrm{cm})\end{array}$ & $\begin{array}{c}\text { SD } \\
(\mathrm{mm})\end{array}$ & $\begin{array}{c}\text { PH } \\
(\mathrm{cm})\end{array}$ & $\begin{array}{c}\text { EIH } \\
(\mathrm{cm})\end{array}$ & $\begin{array}{c}\text { SD } \\
(\mathrm{mm})\end{array}$ \\
\hline $\mathrm{T} 1$ & $165.5 \mathrm{a}$ & $109.6 \mathrm{a}$ & $21.4 \mathrm{~b}$ & $162.5 \mathrm{~b}$ & $110.8 \mathrm{a}$ & $20.9 \mathrm{c}$ \\
\hline $\mathrm{T} 2$ & $144.9 \mathrm{a}$ & $91.5 \mathrm{~b}$ & $20.6 \mathrm{~b}$ & $165.8 \mathrm{~b}$ & $109.1 \mathrm{a}$ & $19.9 \mathrm{c}$ \\
\hline $\mathrm{T} 3$ & $143.3 \mathrm{a}$ & $103.9 \mathrm{a}$ & $20.4 \mathrm{~b}$ & $183.0 \mathrm{a}$ & $115.9 \mathrm{a}$ & $20.1 \mathrm{c}$ \\
\hline $\mathrm{T} 4$ & $134.6 \mathrm{a}$ & $87.6 \mathrm{~b}$ & $21.2 \mathrm{~b}$ & $155.3 \mathrm{~b}$ & $89.6 \mathrm{~b}$ & $20.8 \mathrm{c}$ \\
\hline $\mathrm{T} 5$ & $130.9 \mathrm{a}$ & $87.4 \mathrm{~b}$ & $22.6 \mathrm{a}$ & $132.8 \mathrm{c}$ & $81.4 \mathrm{~b}$ & $21.1 \mathrm{c}$ \\
\hline $\mathrm{T} 6$ & $143.4 \mathrm{a}$ & $86.5 \mathrm{~b}$ & $20.7 \mathrm{~b}$ & $154.5 \mathrm{~b}$ & $100.0 \mathrm{a}$ & $20.2 \mathrm{c}$ \\
\hline $\mathrm{T} 7$ & $118.9 \mathrm{~b}$ & $73.8 \mathrm{c}$ & $22.5 \mathrm{a}$ & $120.1 \mathrm{c}$ & $77.9 \mathrm{~b}$ & $23.7 \mathrm{~b}$ \\
\hline $\mathrm{T} 8$ & $86.0 \mathrm{c}$ & $52.5 \mathrm{~d}$ & $24.3 \mathrm{a}$ & $88.3 \mathrm{~d}$ & $62.3 \mathrm{c}$ & $26.2 \mathrm{a}$ \\
\hline
\end{tabular}

(1) T1 control (0); (T2) V2 $100 \mathrm{~g}_{\text {a.i. ha }}{ }^{-1}$; (T3) $100 \mathrm{~g}_{\text {a.i. }} \mathrm{ha}^{-1}$ at V2 + V3; (T4) $100 \mathrm{~g}$ a.i. ha-1 at V2 + V3 + V4; (T5) $300 \mathrm{~g}_{\text {a.i. ha }}{ }^{-1}$ at V4; (T6) 100 g a.i. ha ${ }^{-1}$ at V2 + V3 + V4 +V5; (T7) 100 g a.i. ha ${ }^{-1}$ at V2 + V3 + V4 + V5 +V6; (T8) 100 g a.i. ha ${ }^{-1}$ at V2 + V3 + V4 + V5 + V6 + V7 Different lowercase letters in the column differ according to the Scott-Knott test $(\mathrm{p}<0.05)$.

respectively (Table 2); for the open-pollinated variety, this difference was $31.8 \mathrm{~cm}$ (Table 3). These results show that there is greater sensitivity to $\mathrm{TE}$ at the stage when maize plants have six fully developed leaves and later. But this response was achieved by sequential applications of $100 \mathrm{~g}$ a.i. ha $\mathrm{h}^{-1}$ in the onset of each new expanded leaf.

With the application of six growth retardants in six maize hybrids, Souza et al. (2012) showed that the smallest plant height was found with the application of the growth retardant mepiquat chloride, and the hybrid P30F53 showed the smallest height. In another study, for the maize 
hybrids Status TL and Maximus TLTG, applications at stages V2, V4, V6 and V8 and doses of 0.0, $187.5,375.0$ and $562.5 \mathrm{~g}$ a.i. $\mathrm{ha}^{-1}$ of $\mathrm{TE}$ did not result in changes in plant height (Zagonel and Ferreira, 2013).

In a study on the grass Agrotis stolonifera, the application of TE that led to the greatest reduction in the growth consisted of reapplications of the product based on thermal time accumulation. It was more effective when reapplications occurred every 200 degree days, compared to 400 and 800 degree days or regular intervals of four weeks at the rate of $50 \mathrm{~g}$ a.i. ha ${ }^{-1}$ of TE (Kreuser and Soldat, 2011).

In Brazilian climatic conditions, the estimated phyllochron for maize is from 44.3 to $34.4{ }^{\circ} \mathrm{C}$ day $^{-1}$ leaf $^{-1}$ (Martins et al., 2012). The present research showed that maize satisfactorily responded to sequential rates of $100 \mathrm{~g}$ a.i. ha ${ }^{-1}$ as its phyllochron progressed in both genotypes. Plants that received sequential applications from V2 to V7 had lower height compared with those that received sequential applications from V2 to V6 (see plant height for T7 vs. T8; Tables 2 and 3).

The reduction in plant height by using TE is possible because this product acts on plants by reducing cell elongation. In this case, TE was applied directly in order to inhibit the elongation of internodes of the plant stem. Such inhibition of internode elongation is due to the obstruction of biosynthesis of active gibberellic acid (GA1) by inhibiting the enzyme GA20 3 beta-hydroxylase (Nakayama et al., 1990). Thus, plant growth inhibition is due to reduction in cell elongation only, but not in cell division (Ervin et al., 2002). These results are supported by the absence of change in the number of leaves and internodes, in both genotypes (Table 1).

The growth and development of plants are regulated by endogenous and environmental factors (Santos and Vieira, 2005). Endogenous factors are controlled at the cellular and molecular level, as well as by plant hormones whose function is to maintain the organism as a whole. The ecological importance of plant hormones lies in the transducing substance because it follows the perception of environmental stimuli and, thus, all plant points are informed of the status of other parts by synthesis or changes in concentration of one or more phytohormones.

In the second season of evaluation, application of $\mathrm{TE}$ reduced ear insertion height for hybrid P30F53HR (Table 2), the TE treatment that has accumulated $600 \mathrm{~g}$ a.i. ha ${ }^{-1}$ and the control (T1 x T8) were more shorter than the control in $65.8 \mathrm{~cm}$ (Table 2). The lowest values were found among the treatments T5, T7, and T8 of the simple hybrid and only T8 of the SCS 154 Fortuna in the second year of the experiment. Sangoi et al. (2002) pointed out that plants with lower plant height and ear insertion height would be more advantageous agronomically because they allow a more balanced center of gravity and a lower level of lodging and stem breakage, thus favoring nutrient absorption for crop production.

In general, stem diameter in the first year of assessment was higher than that observed at second year in both genotypes (Table 4). But among of treatments, the results showed that the largest stem diameters were consistently found in treatments T5, T7 and T8 for the simple hybrid, and in treatment T8 for the open-pollinated variety which had an increase of approximately $6 \mathrm{~mm}$ compared to the control. In a study applying TE on distinct wheat cultivars, the stem diameter decreased in cv. Abalone and increased in cv. RBS Guaramirim (Nardino et al., 2013).

Table 4 - Season effect on the traits: plant height (PH), ear insertion height (EIH), stem diameter (SD), number of leaves per plant (NL), time to tasseling (TT) and biological yield (BY) in two maize genotypes in two growing seasons. Lages-SC, 2015

\begin{tabular}{|c|c|c|c|c|c|c|}
\hline \multicolumn{7}{|c|}{ P30F53HR } \\
\hline Season & $\begin{array}{l}\mathrm{PH} \\
(\mathrm{cm})\end{array}$ & $\begin{array}{l}\mathrm{EIH} \\
(\mathrm{cm})\end{array}$ & $\begin{array}{c}\mathrm{SD} \\
(\mathrm{mm})\end{array}$ & $\begin{array}{c}\mathrm{NL} \\
\left(\mathrm{n}^{\circ} .\right)\end{array}$ & $\begin{array}{c}\text { TT } \\
\text { (days) }\end{array}$ & $\begin{array}{l}\text { BY } \\
(\mathrm{g})\end{array}$ \\
\hline 2013 & $146.2 \mathrm{a}$ & $95.7 \mathrm{a}$ & $22.5 \mathrm{a}$ & $16.3 \mathrm{~b}$ & $78.6 \mathrm{a}$ & $194.3 \mathrm{a}$ \\
\hline 2014 & $120.7 \mathrm{~b}$ & $78.4 \mathrm{~b}$ & $21.0 \mathrm{~b}$ & $18.5 \mathrm{a}$ & $74.6 \mathrm{~b}$ & $90.6 \mathrm{~b}$ \\
\hline \multicolumn{7}{|c|}{ SCS 159 Fortuna } \\
\hline 2013 & $163.2 \mathrm{a}$ & $105.7 \mathrm{a}$ & $22.4 \mathrm{a}$ & $16.6 \mathrm{~b}$ & $79.2 \mathrm{a}$ & $226.6 \mathrm{a}$ \\
\hline 2014 & $127.3 \mathrm{~b}$ & $81.0 \mathrm{~b}$ & $20.9 \mathrm{~b}$ & $19.0 \mathrm{a}$ & $77.8 \mathrm{a}$ & $98.0 \mathrm{~b}$ \\
\hline
\end{tabular}

Different lowercase letters in the column differ according to the Scott-Knott test $(\mathrm{p}<0.05)$. 
This is evidence that the cultivars responded differently to the use of the growth retardant TE. Another experiment led to the similar conclusion about the effect of TE on stem diameter of wheat plants depends on the cultivar, crop management, and weather conditions (Penckowski et al., 2009).

Biological yield of maize plants had the lowest values in the first year assessment for the T6, T7, and T8 treatments of the simple hybrid, and in treatment T7 of SCS 154 Fortuna, and there was no difference among treatments when compared to the second year. However, the second year of evaluation had lower biological yield values than the first year (Table 2). Agricultural maize grain yield can be defined as the product of biological yield and the harvest index. The harvest index, which is the fraction of grains produced compared with the total dry matter of the plant, can be used in the evaluation of the performance of genotypes under different climatic conditions (Donald and Hamblin, 1976). The harvest index can also identify the ability of a genotype to combine high total production capacity and allocate the accumulated dry matter components of economic interest. In maize, the maximum harvest index is approximately 0.52 . Thus, kernel yield is related to morphological and physiological characteristics of the plant according to the different genotypes, however, smaller plants and early-maturing plants result in the highest rates of partitioning, as long as climatic and nutritional requirements are met (Durães et al., 1993).

The number of fully expanded leaves did not change with the use of the regulator on both genotypes (Table 1). However, there were a higher number of leaves for the two genotypes in the second than in the first year of assessment (Table 4). The probable cause for the plant height was more shorter with respectively lower number of leaves per plant, in second season are due average maximum and minimum temperature when values were 21.6 and $11.1{ }^{\circ} \mathrm{C}$ in the first compared to 25.3 and $14.0{ }^{\circ} \mathrm{C}$ in the second season, and sum of the incidence of solar radiation was $702.5 \mathrm{~h}$ in first and $722.5 \mathrm{~h}$ in the second season (Figure 1). Pricinotto et al. (2014) studied the effect of TE on the simple maize hybrid Status Viptera at different rates and at different growth stages, and found no significant differences between treatments for the number of leaves per plant, as was found in the present study.

The highest rate of TE delayed flowering for the hybrid P30F53HR and the cultivar SCS 154 Fortuna by 2 and 4 days, respectively, in the experiment in 2013 (Table 1), and by 4 and 7 days, respectively, in the second year of assessment (Table 2). Delay in flowering was also found for the rice cultivar IRGA $422 \mathrm{CL}$ submitted to different rates of TE at three different times, in a manner dependent on the rate of TE. For example, at $150 \mathrm{~g}$ a.i. ha ${ }^{-1}$ of TE flowering was delayed by 16 days, with a consequent increase in length of the total plant cycle (Estevo, 2013). Reduced growth due to reduced cell elongation with consequent lengthening of the growing season are consequences of using TE, as observed in Meyer Zoysia grass (Zoysia japonica) (Ervin et al., 2002). Plant growth inhibition is only due to the reduction of cell elongation and not to cell division because TE leads to a low level of GA1 as a result of the sharp decrease in the enzyme GA20 3 beta-hydroxylase (Adams et al., 1992; Ervin et al., 2002).

This research has shown promising results for a decrease in the height of maize plants in order to reduce the occurrence of plant lodging and stem breakage in this crop. However, more studies are needed and are being conducted to validate these results in field conditions by adjusting the parameters of rate and time of application so as to offer technical advice to farmers.

In conclusion, the application of trinexapac-ethyl (TE) leads to a potential reduction of final height of maize plants by $45 \%$. Sequential applications of $100 \mathrm{~g}$ a.i. TE ha ${ }^{-1}$ among stages V2 to V7 (T8) were more effective at reducing plant height than applications among V2 and V6 (T7) consistently for both maize genotypes contrasting in genetic variability. Thus, it can be inferred that there is greater sensitivity to TE from stage V6 onwards. Increased sequential application of the TE result in a decrease in plant height, ear height and biological maize crop yield.

\section{ACKNOWLEDGEMENTS}

This work was supported by the PROAP/CAPES, by PROMOP/UDESC scholarship for the MENDES FAGHERAZZI, M. and CNPq Research Productivity Scholarship, Brazil, for the SOUZA, C.A. 


\section{REFERENCES}

Adams R. et al. Studies on action of the new growth retardant CGA 163935 (cimectacarb). In: Karsen C.M., van Lonn L.C., Vreugdenhil D., editors. Progress in plant growth regulation. Dordrecht: Kluwer Academic, 1992. p.818-27.

Almeida M.L. et al. Incremento na densidade de plantas: uma alternativa para aumentar o rendimento de grãos de milho em regiões de curta estação estival de crescimento. Ci. Rural. 2000;30:23-9.

Assis J.P. et al. Simulação estocástica de atributos do clima e da produtividade potencial de milho utilizando-se distribuição triangular. Pesq Agropec Bras. 2006;41:539-43.

Comissão de Química e Fertilidade do Solo - CQFSRS/SC. Manual de adubação e de calagem para os Estados do Rio Grande do Sul e Santa Catarina. 10ª.ed. Porto Alegre: SBCS - Núcleo Regional Sul/UFRGS, 2004. 400p.

Companhia Nacional de Abastecimento - Conab. Acompanhamento safra brasileira: grãos, décimo primeiro levantamento, safra 2013/14, v.1, n. 11, 2014. [acesso em: 08 set. 2014] Disponível em: http://www.conab.gov.br/OlalaCMS/uploads/arquivos/ 14_08_07_08_59_54_boletim_graos_agosto_2014.pdf.

Davies, P.J. The plant hormones: their nature, occurrence, and functions. In: Davies, P.J., editor. Plant hormones and their role in plant growth and development. The Netherland: Kluwer Academic, 1987. p.1-23.

Donald C.M., Hamblin J. The biological yield and harvest index of cereal as agronomic and plant breeding criteria. Adv Agron. 1976;28:361-405.

Durães F.O.M. et al. Partição de fitomassa e limitações de rendimento de milho (Zea mays L.) relacionados com a fonte-dreno. Rev Bras Fis Veg. 1993;5:110-20.

Estevo P.A. Efeito do regulador de crescimento trinexapac-ethyl em cultivares de arroz irrigado. [Dissertação] Santa Maria: Universidade Federal de Santa Maria, 2013. 74 p.

Ervin E.H. et al. Trinexapac-ethyl restricts shoot growth and progress stand density of 'Meyer' zoysiagrass fairway under shade. HortScience. 2002;37:502-5.

Ferreira D.F. SISVAR: a computer statistical analysis system. Cienc Agrotec. 2011;35:1039-42.

Food and Agriculture Organization of the United Nations - FAO. FAOSTAT-Agriculture, Production, Crops, 2014. [accessed at: 2 mar. 2014] Available on: http://faostat.fao.org/default.aspx..

Gong F.P. et al. Making better maize plants for sustainable grain production in a changing climate. Front Plant Sci. 2015;6:1-6.

Grupo Cultivar de Publicações. Cultivar grandes culturas. 2012;159:1-44.

Heckman N.L. et al. Influence of trinexapac-ethyl on respiration of isolated wheat mitochondria. Crop Sci. 2002;42:423-7.

Kreuser W.C., Soldat D.J. A growing degree day model to schedule trinexapac-ethyl applications on Agrostis stolonifera golf putting greens. Crop Sci. 2011;51:2228-36.

Martins J.D. et al. Estimativa do filocrono em milho para híbridos com diferentes ciclos de desenvolvimento vegetativo. Ci Rural. 2012;42:777-83.

Nakayama I. et al. Effects of a plant-growth regulator, prohexadione, on the biosynthesis of gibberellins in cell-free systems derived from immature seeds. Plant Cell Physiol. 1990;31:1183-90.

Nardino M. et al. Resposta de cultivares de trigo a doses de nitrogênio e à aplicação de redutor de crescimento. Cur Agr Sci Technol. 2013;19:73-81.

Perez-Perez J.M. Hormone signaling and root development: an update on the latest Arabidopsis thaliana research. Funct Plant Biol. 2007;34:163-71.

Penckowski L.H. et al. Nitrogênio e redutor de crescimento em trigo de alta produtividade. Acta Sci Agron. 2009;31:473-9. 
Pricinotto L.F. et al. Trinexapac-ethyl no desenvolvimento vegetativo de milho. [CD-ROM] In: Anais do Congresso Nacional de Milho e Sorgo. Sete Lagoas: ABMS, 2014.

Ritchie S.W. et al. How a corn plant develops. Ames, Iowa State University of Science and Technology, 1993. 26p. (Special Report, 48).

Sangoi L. et al. Desempenho agronômico do milho em razão do tratamento de sementes com Azospirillum sp. e da aplicação de doses de nitrogênio mineral. Rev Bras Ci Solo. 2015;39:1141-50.

Sangoi L. et al. Senescência foliar e resposta de híbridos de milho cultivados em diferentes épocas ao adensamento. Rev Bras Milho Sorgo. 2013;12:21-32.

Sangoi L. et al. Response of Brazilian maize hybrids from different eras to changes in plant density. Field Crops Res. 2002;79:39-51.

Santos C.M., Vieira E.L. Efeito de bioestimulante na germinação de sementes, vigor de plântulas e crescimento inicial do algodoeiro. Magistra. 2005; 17:124-30.

Silva P.R.F. et al. Arranjo de plantas e sua importância na definição da produtividade em milho. Porto Alegre: Evangraf, 2006. 63p.

Souza C.A. et al. Efeito de redutores de crescimento sobre atributos morfológicos da planta e componentes do rendimento em milho. In: Anais do 22․ Seminário de Iniciação Científica. Lages: Universidade do Estado de Santa Catarina, 2012. p.58.

Weiler E.W., Adams R. Studies on the action of the new growth retardant CGA 163'935. In: Proceedings of the Brighton Crop Protection Conference-Weeds. 1991. p.1133-8.

Zagonel J., Fernandes E.C. Doses e épocas de aplicação de redutor de crescimento afetando cultivares de trigo em duas doses de nitrogênio. Planta Daninha. 2007;25:331-9.

Zagonel J., Ferreira C. Doses e épocas de aplicação de regulador de crescimento em híbridos de milho. Planta Daninha. 2013;31:395-402.

Zhang Q. et al. Maize yield and quality in response to plant density and application of a novel plant growth regulator. Field Crops Res. 2014;164:82-9. 